\title{
Aircraft observations of water-soluble dicarboxylic acids in the aerosols over China
}

\author{
Yan-Lin Zhang ${ }^{1,2}$, Kimitaka Kawamura ${ }^{2}$, Ping Qing $\mathrm{Fu}^{2,3}$, Suresh K. R. Boreddy ${ }^{2}$, Tomomi Watanabe ${ }^{2}$, \\ Shiro Hatakeyama ${ }^{4,5}$, Akinori Takami ${ }^{5}$, and Wei Wang ${ }^{6, \dagger}$ \\ ${ }^{1}$ Yale-NUIST Center on Atmospheric Environment, Nanjing University of Information Science \\ and Technology, Nanjing 10044, China \\ ${ }^{2}$ Institute of Low Temperature Science, Hokkaido University, Sapporo 060-0819, Japan \\ ${ }^{3}$ LAPC, Institute of Atmospheric Physics, Chinese Academy of Sciences, Beijing 100029, China \\ ${ }^{4}$ Institute of Symbiotic Science and Technology, Tokyo University of Agriculture and Technology, \\ Fuchu, Tokyo 183-8509, Japan \\ ${ }^{5}$ National Institute for Environment Studies, Tsukuba, Ibaraki 305-8506, Japan \\ ${ }^{6}$ Chinese Research Academy of Environmental Sciences, Beijing 100012, China \\ $\dagger$ deceased
}

Correspondence to: Yan-Lin Zhang (dryanlinzhang@gmail.com, dryanlinzhang@outlook.com) and Kimitaka Kawamura (kawamura@lowtem.hokudai.ac.jp)

Received: 4 January 2016 - Published in Atmos. Chem. Phys. Discuss.: 1 February 2016

Revised: 6 May 2016 - Accepted: 16 May 2016 - Published: 25 May 2016

\begin{abstract}
Vertical profiles of dicarboxylic acids, related organic compounds and secondary organic aerosol (SOA) tracer compounds in particle phase have not yet been simultaneously explored in East Asia, although there is growing evidence that aqueous-phase oxidation of volatile organic compounds may be responsible for the elevated organic aerosols (OA) in the troposphere. Here, we found consistently good correlation of oxalic acid, the most abundant individual organic compounds in aerosols globally, with its precursors as well as biogenic-derived SOA compounds in Chinese tropospheric aerosols by aircraft measurements. Anthropogenically derived dicarboxylic acids (i.e., $\mathrm{C}_{5}$ and $\mathrm{C}_{6}$ diacids) at high altitudes were 4-20 times higher than those from surface measurements and even occasionally dominant over oxalic acid at altitudes higher than $2 \mathrm{~km}$, which is in contrast to the predominance of oxalic acid previously reported globally including the tropospheric and surface aerosols. This indicates an enhancement of tropospheric SOA formation from anthropogenic precursors. Furthermore, oxalic acid-tosulfate ratio maximized at altitudes of $\sim 2 \mathrm{~km}$, explaining aqueous-phase SOA production that was supported by good correlations with predicted liquid water content, organic carbon and biogenic SOA tracers. These results demonstrate
\end{abstract}

that elevated oxalic acid and related SOA compounds from both the anthropogenic and biogenic sources may substantially contribute to tropospheric OA burden over polluted regions of China, implying aerosol-associated climate effects and intercontinental transport.

\section{Introduction}

Water-soluble dicarboxylic acids (diacids), one of the most abundant organic aerosol (OA) constituents, have been reported in the marine (Kawamura and Sakaguchi, 1999), remote (Kawamura et al., 1996), desert (Sorooshian et al., 2012), mountainous, rural, semi-urban and urban atmosphere (Ho et al., 2007). As important components of aerosols, diacids play an important role in Earth's climate by directly scattering sunlight or indirectly by enhancing the ability of $\mathrm{OA}$ to act as cloud condensation nuclei (CCN) (Pradeep Kumar et al., 2003). They can contribute to wide ranges from a few percent of the water-soluble mass (Sorooshian et al., 2007b), which could serve as tracers for the atmospheric processing of water-soluble OA (Ervens et al., 2011), to more 
than $10 \%$ of organic carbon (OC) in the remote marine atmosphere (Kawamura and Sakaguchi, 1999).

Diacids in aerosols may be directly emitted from fossilfuel combustion (e.g. vehicle exhaust) (Kawamura and Kaplan, 1987), biomass burning (Narukawa et al., 1999) and cooking emissions (Rogge et al., 1991). They can also be formed by degradation from unsaturated fatty acids (Kawamura et al., 1996) and cyclic alkenes (Hatakeyama et al., 1987). Laboratory studies have provided direct experimental evidence that stepwise aqueous oxidation of relatively longer-chain $(n)$ dicarboxylic acids can yield the corresponding short-chain $(n-1)$ dicarboxylic acids (Enami et al., 2015). In addition, in-cloud and below-cloud measurements as well as other field measurements have revealed that aqueous-phase oxidation of volatile organic compounds (VOCs) and intermediates such as glyoxal (Gly), methylglyoxal (MeGly) and pyruvic acid (Pyr) in wet aerosols or clouds and the subsequent gas-particle partitioning are more important pathways for the production of small diacids such as oxalic and malonic acids (Lim et al., 2013; Carlton et al., 2007; Lim et al., 2005; Carlton et al., 2006; Yu et al., 2005; Sorooshian et al., 2007b, 2006; Zhang et al., 2016a). Oxalic acid $\left(\mathrm{C}_{2}\right)$ is the most abundant diacid with concentrations ranging from a few $\mathrm{ng} \mathrm{m}^{-3}$ in remote locations (Kawamura et al., 1996) to hundreds or even up to $1000 \mathrm{ng} \mathrm{m}^{-3}$ in urban regions (Ho et al., 2007) and highly forested regions (Falkovich et al., 2005). Indeed, from a model study it has been proposed that photochemical oxidation of isoprene and subsequent partitioning of water-soluble photooxidation products into the aqueous phase is a predominant formation pathway of oxalic acid (Myriokefalitakis et al., 2011). Most of the previous studies of diacids and other organic compounds in aerosols have been conducted at ground surface; however, only a few aircraft observations have been conducted over the arctic region (Talbot et al., 1992), the western North Pacific (Narukawa et al., 1999), the western rim of the Pacific Ocean (Kawamura et al., 2003), the coastal marine stratocumulus and cumulus clouds over USA (Crahan et al., 2004; Sorooshian et al., 2013, 2007a; Wonaschuetz et al., 2012; Prabhakar et al., 2014) and over inland agricultural and urban areas in the western USA (Sorooshian et al., 2015). These aircraft experiments have revealed that water-soluble diacids may be produced by the photochemical oxidation of anthropogenic organic compounds in the atmosphere and thus play an important role in controlling the chemical and physical properties of OA in the troposphere. However, the evidence of secondary production of diacids (i.e., oxalic acid) in tropospheric aerosols may not be enough due to the lack of data sets from simultaneous measurements of their possible precursors and/or intermediates, such as particle-phase Gly, MeGly, Pyr and glyoxylic acid $\left(\omega \mathrm{C}_{2}\right)$, as well as other secondary organic aerosol (SOA) compounds from photochemical oxidation of VOCs such as isoprene and monoterpenes in the aerosols collected from aircraft campaigns.
East Asia is one of the most important source regions of OA (Zhang et al., 2007), and this is especially true for China due to the rapid urbanization, industrialization and energy consumption (Huang et al., 2014; Zhang et al., 2015a; Zhang and Cao, 2015). Elevated OA were found in the free troposphere from ACE-Asia (Asia-Pacific Regional Aerosol Characterization Experiment Science) aircraft observations, exceeding model-predicted organic aerosols by a factor of 10-100 (Heald et al., 2011, 2005; Henze and Seinfeld, 2006). There is growing evidence that SOA formation from aqueous-phase processing of VOCs, especially from isoprene, may partially explain the missing OA in the troposphere over East Asia (Heald et al., 2011, 2005; Henze and Seinfeld, 2006); however, vertical profiles of diacids, related organic compounds (i.e., ketoacids and $\alpha$ dicarbonyls) and SOA tracer compounds in particle phase have not yet been simultaneously analyzed in this region. Additional chemical constraints (e.g. simultaneously measuring different types of organic aerosols such as diacids, ketoacids and $\alpha$-dicarbonyls and SOA tracer compounds) are urgently required to investigate the importance of $\mathrm{SOA}$ formation pathway to the global/regional budget of OA. Our previous studies have reported the molecular composition of primary organic aerosols (POA) including n-alkanes, fatty acids, sugars and polycyclic aromatic hydrocarbons (PAHs) as well as biogenic SOA tracers in aerosol particles over China (Wang et al., 2007; Fu et al., 2014). However, chemical composition and molecular distribution of diacids have never been reported by aircraft measurements over mainland and coastal China, although only limited studies have been conducted on their spatial distributions based ground observations (Ho et al., 2007).

In this study, we have collected aerosol samples over coastal to inland China using aircraft during spring, summer and winter. The samples were analyzed for a series of diacids and related compounds as well as SOA tracer compounds to investigate the vertical profiles, possible sources and formation pathways of diacids and related organic compounds in the polluted troposphere over China. In light of these analyses, we observed that production of oxalic acid and related compounds from anthropogenic and biogenic precursors is enhanced at high altitudes in the troposphere.

\section{Materials and methods}

\subsection{Aircraft campaigns}

Aircraft measurements were carried out over the coastal East China Sea in winter (25 December 2002-6 January 2003, $n=18$ ) and inland China during summer (8 August 200313 September 2003, $n=14$ ) and spring (19 May 200410 June 2004, $n=16$ ) using Yun-12 and Yun-5 airplanes as described elsewhere (Wang et al., 2007; Fu et al., 2014). The sampling heights were from 500 to $3000 \mathrm{~m}$ (with un- 
certainty of around $10 \%$ ) above ground level across many major cities such as Changzhou, Nanjing, Hefei, Wuhan, Chongqing and Chengdu for inland aerosol samples as well as Wenzhou, Ningbo, Shanghai, Changzhou, Qingdao and Dalian for coastal aerosol samples. The detailed flight tracks and flight information are shown in Fig. 1 and Table S1 (see Supplement). $\mathrm{PM}_{2.5}$ aerosols were collected on a pre-heated quartz fiber filter (diameter of $90 \mathrm{~mm}$ ) using a mediumvolume air sampler (Beijing Geological Instrument Factory, China). Aerosol samples were collected for the sampling period from ca. $80 \mathrm{~min}$ to $2 \mathrm{~h}$. Air was taken via an inlet installed below the cabin of the aircraft at a flow rate of $78 \mathrm{~L} \mathrm{~min}^{-1}$. The lack of using organic denuders may lead to a positive artifact (e.g., $10 \%$ of the organic carbon) by possible adsorption of gas-phase organic acids on the quartz filters (Cheng et al., 2009), but this will not affect our conclusions. Because air conditioning was not available in the aircraft, the ambient temperatures inside and outside the cabin should be similar, and thus potential adsorption of gaseous organic acids on the quartz filter should be minimal.

\subsection{Measurement of diacids}

Diacids and related organic compounds such as $\omega$ oxocarboxylic acids (or oxoacids), pyruvic acid and $\alpha$ dicarbonyls were determined as described elsewhere (Kawamura and Ikushima, 1993; Ho et al., 2010). Briefly, the sample and blank filters were extracted with organic free ultrapure water $(10 \mathrm{~mL} \times 3)$ in a glass vial for $10 \mathrm{~min}$. To remove insoluble particles and filter debris, the extracts were passed through a Pasteur pipette packed with quartz wool. The combined extracts were concentrated using a rotary evaporator under a vacuum and then further concentrated using a nitrogen blow-down system. The concentrated extracts were reacted with $14 \% \mathrm{BF}_{3} / \mathrm{n}$-butanol to derive carboxyl group to dibutyl ester and oxo group to dibutoxy acetals.

The derivatives were extracted with $\mathrm{n}$-hexane, concentrated to near dryness, dissolved with n-hexane in $1.5 \mathrm{~mL}$ glass vials. The samples were finally determined using a gas chromatography (GC; HP6980) with a split/splitless injection, fused silica capillary column (HP-5, $0.2 \mathrm{~mm}$ i.d. $\times 25 \mathrm{~m}$ long $\times 0.52 \mu \mathrm{m}$ film thickness) and a flame ionization detector. Identification of the compounds was performed by GC retention times with those of authentic standards and $\mathrm{GC} /$ mass spectrometry analyses. Recoveries of authentic standards spiked to a pre-heated quartz fiber filter were generally better than $85 \%$ for all organic compound identified except for oxalic acid (78\%), pyruvic acid (72\%) and methylglyoxal $(55 \%)$. Duplicate analyses of filter samples from other sites indicated that analytical errors are smaller than $15 \%$. During the aircraft campaigns, field blank filters were mounted onto the sampler for seconds without pumping. Blank and sample filters were placed individually in a clean (pre-combusted at $450{ }^{\circ} \mathrm{C}$ for $6 \mathrm{~h}$ ) glass jar sealed with
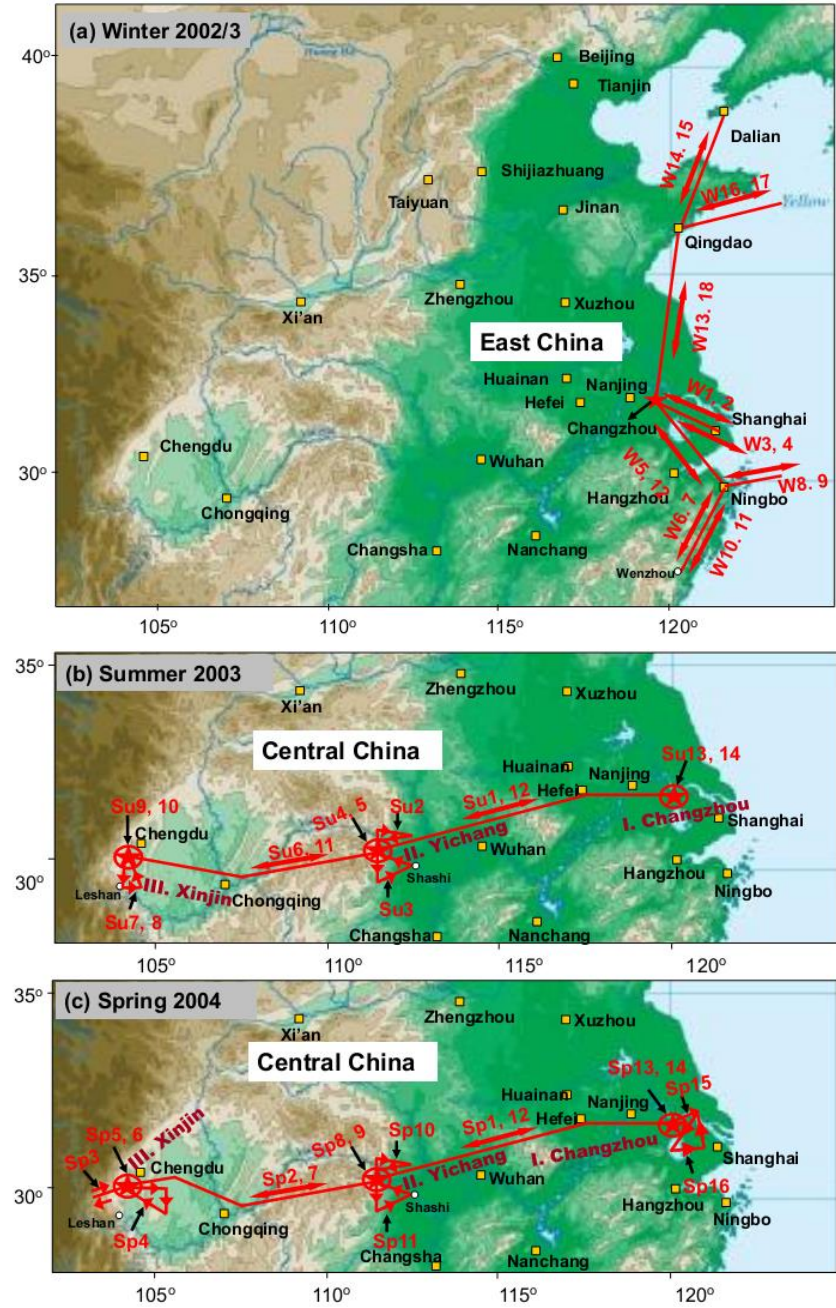

Figure 1. Tracks of research flights during aircraft measurements over China during (a) winter 2002, (b) summer 2003 and (c) spring 2004. The detailed sampling information with flight no. is listed in Table S1 in the Supplement. The maps with the flight tracks were drawn with the software of PowerPoint 2010, https://products. office.com/

a Teflon-lined screw cap, transported to the laboratory, and stored at $-20^{\circ} \mathrm{C}$ prior to analysis (Wang et al., 2007).

Small peaks of oxalic, malonic and glyoxylic acids were found in the field and lab blanks, but they were smaller than $10 \%$ of the real samples. The concentrations reported here are all corrected for the field blanks but not for the recoveries. The method of SOA tracer measurement was described elsewhere (Fu et al., 2014).

\subsection{Measurements of EC and OC}

The concentrations of OC and elemental carbon (EC) were measured with thermal-optical transmittance method by an OC/EC Carbon Aerosol Analyzer (Sunset Laboratory Inc., 
USA) following the IMPROVE protocol (Chow et al., 2004). All the analyses of the filter samples were completed in 2006.

\subsection{Estimation of liquid water content and aerosol acidity}

Liquid water content (LWC) and aerosol acidity were predicted by ISORROPIA II, which is a thermodynamic equilibrium model with robust and rapid convergence for all aerosol types (Fountoukis and Nenes, 2007). Measured concentrations of water-soluble inorganic ions, ambient temperature and relative humility were used as input.

\section{Results and discussion}

\subsection{Concentrations and molecular distributions}

Total concentrations of diacids and related compounds quantified in the inland aircraft $\mathrm{PM}_{2.5}$ (i.e., particulate matter with a diameter smaller than $2.5 \mu \mathrm{m}$ ) are $730 \pm 328$ and $586 \pm 457 \mathrm{ng} \mathrm{m}^{-3}$ during summer and spring, respectively, while in the coastal aerosols, the average concentration is $254 \pm 209 \mathrm{ng} \mathrm{m}^{-3}$ in winter (Table 1). It is of great interest to note that the concentrations of diacids in the troposphere over the Arctic and North Pacific are generally much lower than those reported at ground levels (Kawamura et al., 1996; Kawamura and Sakaguchi, 1999); however, the concentrations in the troposphere over mainland China are within the range of or even higher than those reported at ground levels in major cities (Ho et al., 2007; Kawamura and Ikushima, 1993). Due to the enhanced anthropogenic emissions, concentrations of POA (i.e., n-alkanes, fatty acids, sugars, lignin and resin products, sterols, PAHs and phthalic acids) are higher in winter than those in summer and spring (Wang et al., 2007). In contrast, the concentrations of diacids in summer and spring are $2-15$ times higher than those in winter, indicating that these compounds are mostly of secondary origin via the oxidation of their gaseous precursors such as isoprene and $\alpha / \beta$-pinene (Kanakidou et al., 2005; Carlton et al., 2006, 2007, 2009; Ervens et al., 2011) as discussed below.

Molecular distributions of diacids $\left(\mathrm{C}_{n}\right.$ is $n$-numbered carbon diacid) in our study are generally characterized by the predominance of $\mathrm{C}_{2}$ followed by succinic $\left(\mathrm{C}_{4}\right)$ and malonic $\left(\mathrm{C}_{3}\right)$ acids during spring and winter, being consistent with previous findings obtained in Chinese megacities (Ho et al., 2007) (Fig. 2a). However, in many summer samples collected at heights of above $2 \mathrm{~km}$, we found the predominance of glutaric $\left(\mathrm{C}_{5}\right)$ and adipic $\left(\mathrm{C}_{6}\right)$ acids (see Fig. $2 \mathrm{~b}$ ), which are the major organic compounds produced by the oxidation of anthropogenic cyclohexene and methylenecyclohexane (Hamilton et al., 2006; Muller et al., 2007). Although $\mathrm{C}_{5}$ and $\mathrm{C}_{6}$ diacids are the ozonolysis products in smog chamber studies, Pavuluri et al. (2015) recently proposed that $\mathrm{C}_{5}$ and $\mathrm{C}_{6}$ are produced by photochemical processing of aqueous aerosols from a laboratory study. Such a molecular distri-
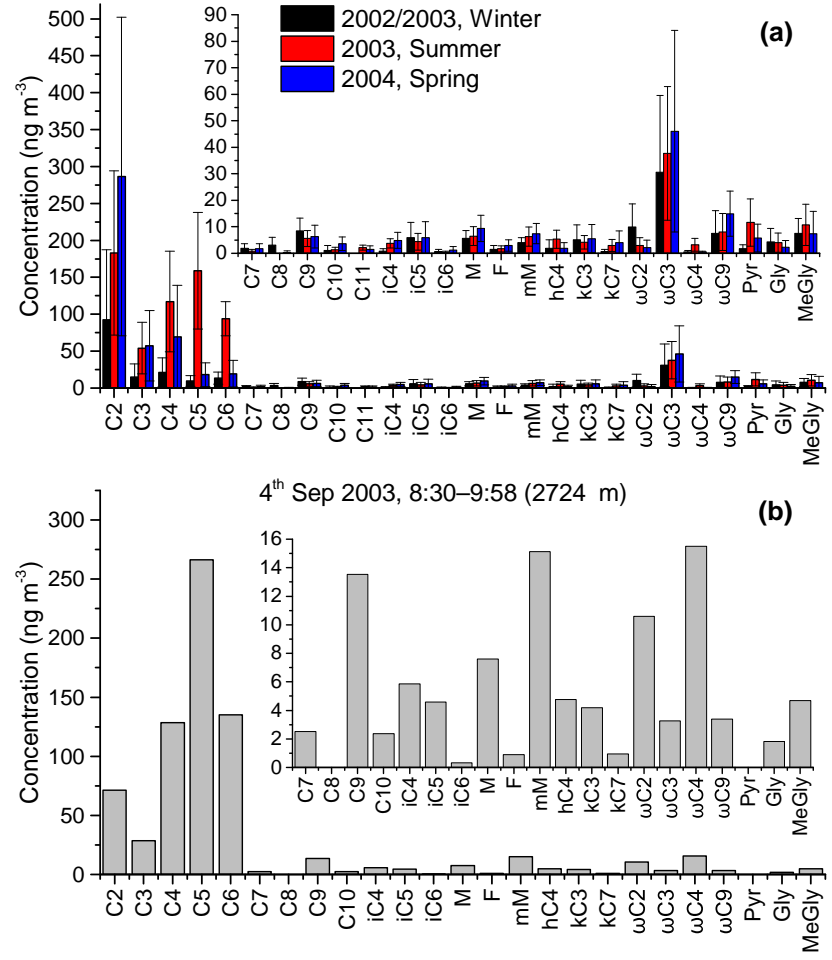

Figure 2. Molecular distributions of straight chain diacids $\left(\mathrm{C}_{2}-\right.$ $\mathrm{C}_{11}$ ), branched chain diacids $\left(\mathrm{iC}_{4}-\mathrm{iC}_{6}\right)$, unsaturated diacids $(\mathrm{M}, \mathrm{F}$ and $\mathrm{mM})$, multifunctional diacids $\left(\mathrm{hC}_{4}, \mathrm{kC}_{3}\right.$ and $\left.\mathrm{kC}_{7}\right)$, ketoacids $\left(\omega \mathrm{C}_{2}-\omega \mathrm{C}_{4}, \omega \mathrm{C}_{9}\right.$ and Pyr), and $\alpha$-dicarbonyls (Gly and MeGly) in aircraft measurement over China; (a) averaged concentrations with bars of standard deviation during winter 2002/2003, summer 2003 and spring 2004; (b) molecular distributions of the measured compounds in the sample collected on 4 September 2003. See Table 1 for abbreviations.

bution has not been reported for the tropospheric and ground level aerosols (Hatakeyama et al., 1987; Enami et al., 2015; Kawamura and Bikkina, 2016). In our measurements, the averaged concentrations of $\mathrm{C}_{5}$ and $\mathrm{C}_{6}$ in summer are $159 \pm 79$ and $93.9 \pm 23.2 \mathrm{ng} \mathrm{m}^{-3}$, which are 4-20 times higher than those in ground measurements in Tokyo (Kawamura and Yasui, 2005), Los Angeles (Kawamura and Kaplan, 1987) and in many megacities in China (Ho et al., 2007). Such high abundances of $\mathrm{C}_{5}$ and $\mathrm{C}_{6}$ observed in summer imply an important formation pathway associated with enhanced photochemical oxidation of anthropogenic precursors in the polluted troposphere over China.

\section{2 $\mathrm{C}_{3}\left(\mathrm{C}_{2}\right)$ to $\mathrm{C}_{4}$ ratio}

The malonic to succinic acid $\left(\mathrm{C}_{3} / \mathrm{C}_{4}\right)$ ratios can provide information on source, formation pathways and photochemical aging of organic aerosols. $\mathrm{C}_{3} / \mathrm{C}_{4}$ ratios in aerosols derived from vehicular exhausts (i.e., $0.25-0.44$, average (av.) 0.35) (Kawamura and Kaplan, 1987) have lower values than those in ambient aerosols from Tokyo (i.e., 0.56-2.9, av. 
Table 1. Average concentrations $\left(\mathrm{ng} \mathrm{m}^{-3}\right)$ and concentration ranges $\left(\mathrm{ng} \mathrm{m}^{-3}\right)$ for straight chain diacids $\left(\mathrm{C}_{2}-\mathrm{C}_{11}\right)$, branched chain diacids $\left(\mathrm{iC}_{4}-\mathrm{iC}_{6}\right)$, unsaturated diacids $(\mathrm{M}, \mathrm{F}$ and $\mathrm{mM})$, multifunctional diacids $\left(\mathrm{hC}_{4}, \mathrm{kC}_{3}\right.$ and $\left.\mathrm{kC}_{7}\right)$, oxoacids $\left(\omega \mathrm{C}_{2}-\omega \mathrm{C}_{4}, \omega \mathrm{C}_{9}\right.$, and $\left.\mathrm{Pyr}\right)$ and $\alpha-$ dicarbonyls (Gly and MeGly) of aerosol samples collected by aircraft campaigns over China.

\begin{tabular}{|c|c|c|c|c|c|c|}
\hline & \multicolumn{2}{|c|}{$\begin{array}{l}2003 \text { Summer } \\
\text { (inland China) }\end{array}$} & \multicolumn{2}{|c|}{$\begin{array}{l}2004 \text { Spring } \\
\text { (inland China) }\end{array}$} & \multicolumn{2}{|c|}{$\begin{array}{l}\text { 2002/2003 Winter } \\
\text { (coastal China) }\end{array}$} \\
\hline & Range & Mean $\left(\mathrm{SD}^{\mathrm{a}}\right)$ & Range & Mean (SD) & Range & Mean (SD) \\
\hline Oxalic, $\mathrm{C}_{2}$ & $36.4-401$ & $183(111)$ & $76.5-918$ & $286(216)$ & $13.3-425$ & $92.6(94.5)$ \\
\hline Malonic, $\mathrm{C}_{3}$ & $6.3-131$ & $54(35)$ & $12.2-216$ & $57.5(47.6)$ & $1.4-79$ & $15(17.9)$ \\
\hline Succinic, $\mathrm{C}_{4}$ & $9.4-277$ & $117(68.2)$ & $16-319$ & $69.1(69.9)$ & $2.3-87.9$ & $21.4(19.8)$ \\
\hline Glutaric, $\mathrm{C}_{5}$ & $20.7-289$ & $159(79.1)$ & $6.5-73.8$ & $18.1(16.3)$ & $0.9-26.1$ & $9.7(7.3)$ \\
\hline Adipic, $\mathrm{C}_{6}$ & $52.3-135$ & $93.9(23.2)$ & $5.7-69$ & $19.4(18.1)$ & $3.7-34.5$ & $13.4(8.1)$ \\
\hline Pimelic, $\mathrm{C}_{7}$ & $0-2.5$ & $0.8(0.7)$ & n.d. -8.1 & $1.7(2)$ & $0.3-7.5$ & $1.9(1.7)$ \\
\hline Suberic, $\mathrm{C}_{8}$ & n.d. ${ }^{\text {b }}$ & n.d. & n.d. -2.7 & $0.2(0.7)$ & n.d. -11 & $3.2(2.9)$ \\
\hline Azelaic, $\mathrm{C}_{9}$ & $2-13.5$ & $5.6(3)$ & $2.4-18.2$ & $6.3(4.3)$ & $2.9-20.6$ & $8.5(4.8)$ \\
\hline Sebacic, $C_{10}$ & $0.3-3.6$ & $1.3(1.0)$ & n.d. -8.4 & $3.6(2.5)$ & $0-6.9$ & $1.1(1.8)$ \\
\hline Undecanedioic, $\mathrm{C}_{11}$ & $0.8-4.3$ & $2.1(0.9)$ & n.d. -4.3 & $1.5(1.3)$ & n.d. & n.d. \\
\hline Methylmalonic, $\mathrm{iC}_{4}$ & $1.2-5.9$ & $3.7(1.7)$ & $1.1-12.5$ & $4.9(3)$ & $0-3.9$ & $0.9(0.9)$ \\
\hline Methylsuccinic, $\mathrm{iC}_{5}$ & $0.6-10.8$ & $4.4(3.1)$ & $1.3-27.5$ & $5.9(6.1)$ & $0.7-23.2$ & $5.9(5.8)$ \\
\hline Methylglutaric, $\mathrm{iC}_{6}$ & n.d. -1.3 & $0.4(0.4)$ & $0.4-5.9$ & $1.2(1.3)$ & n.d. -2.8 & $0.7(0.8)$ \\
\hline Maleic, M & $1.8-12.5$ & $6.5(3.6)$ & $3.3-22.3$ & $9.4(5)$ & $1.6-11.1$ & $5.7(2.9)$ \\
\hline Fumaric, F & $0.1-3.9$ & $1.7(1.1)$ & $0.5-8.4$ & $3.0(2.1)$ & $0.1-6.2$ & $1.5(1.5)$ \\
\hline Methylmaleic, mM & $2.3-15.1$ & $6.3(3.6)$ & $2.2-18.0$ & $7.4(3.8)$ & $1.3-8.2$ & $4(2)$ \\
\hline Hydroxysuccinic, $\mathrm{hC}_{4}$ & $1.7-12.5$ & $5.3(3.4)$ & n.d. -9.3 & $1.9(2.2)$ & n.d. -13.7 & $1.9(3.2)$ \\
\hline Ketomalonic, $\mathrm{kC}_{3}$ & $0.4-9.2$ & $4.2(2.5)$ & n.d. -22.8 & $5.6(5.3)$ & n.d.-26 & $5.1(5.6)$ \\
\hline Ketopimelic, $\mathrm{kC}_{7}$ & $0.4-8.2$ & $3.0(2.3)$ & n.d. -18.7 & $4.0(4.5)$ & n.d. -3.9 & $0.6(0.9)$ \\
\hline Total diacids & $139-1230$ & $653(290)$ & $148-1780$ & $507(402)$ & $40.4-757$ & 193 (164) \\
\hline n.s. $\mathrm{C}_{2}-\mathrm{C}_{11}$ & $128-1160$ & $615(272)$ & $128-1630$ & $464(371)$ & $31.3-678$ & 167 (149) \\
\hline Pyruvic acid, Pyr & n.d. -9.6 & $2.9(3.0)$ & $0.1-11.4$ & $2.1(2.8)$ & $0.7-36.5$ & $10(8.6)$ \\
\hline Glyoxylic, $\omega \mathrm{C}_{2}$ & $8.1-89.6$ & $37.7(25.2)$ & $8.3-146$ & $46.0(38.0)$ & $6.7-129$ & $30.6(28.9)$ \\
\hline 3-oxopropanoic, $\omega \mathrm{C}_{3}$ & $0.1-9.7$ & $3.3(2.4)$ & $0.1-1.1$ & $0.5(0.3)$ & n.d.-1.9 & $0.5(0.5)$ \\
\hline 4-oxobutanoic, $\omega \mathrm{C}_{4}$ & $0-23.1$ & $8.0(7.0)$ & $6.8-38.9$ & $14.9(8.5)$ & $0.6-35.5$ & $7.5(8.6)$ \\
\hline 9-oxononoic, $\omega \mathrm{C}_{9}$ & $3.4-36.2$ & $11.6(8.9)$ & $0.3-20.5$ & $5.8(5.2)$ & $0.2-5.5$ & $1.8(1.4)$ \\
\hline Total Keto acid & $18.7-131$ & $63.5(36.0)$ & $23.7-178$ & $69.3(48.5)$ & $12.2-176$ & $50.0(36.9)$ \\
\hline Glyoxal, Gly & $0.7-14.8$ & $4.0(3.6)$ & $0.2-9.5$ & $2.3(2.5)$ & $0.6-23$ & $4.3(5.1)$ \\
\hline Methylglyoxal, MeGly & $0.6-28.2$ & $10.8(7.7)$ & $0.8-27.3$ & $7.4(8.3)$ & $2.5-24.3$ & $7.6(5.6)$ \\
\hline Total dicabonyls & $1.3-42.9$ & $14.8(11.1)$ & $1.7-36.8$ & $9.8(10.7)$ & $3.1-47.3$ & $11.8(10.5)$ \\
\hline Total & $170-1390$ & $731(329)$ & $174-1990$ & $586(457)$ & $68.5-980$ & 255 (209) \\
\hline Gly/MeGly & $0.1-1.2$ & $0.4(0.2)$ & $0.04-1.0$ & $0.4(0.3)$ & $0.2-0.9$ & $0.5(0.2)$ \\
\hline $\mathrm{M} / \mathrm{F}$ & $1.7-13.9$ & $4.9(2.9)$ & $1.1-13.8$ & $4.5(3.1)$ & $1.6-27.4$ & $6.8(6.2)$ \\
\hline$\omega \mathrm{C}_{2} / \mathrm{C}_{2}$ & $0.1-0.2$ & $0.2(0.03)$ & $0.1-0.3$ & $0.2(0.04)$ & $0.2-0.8$ & $0.4(0.1)$ \\
\hline $\mathrm{C}_{2} / \mathrm{C}_{4}$ & $0.6-6.7$ & $2.0(1.6)$ & $2.9-5.9$ & $4.6(0.9)$ & $2.8-13.5$ & $4.6(2.3)$ \\
\hline $\mathrm{C}_{3} / \mathrm{C}_{4}$ & $0.2-1.9$ & $0.5(0.42)$ & $0.7-1.1$ & $0.9(0.1)$ & $0.4-1.7$ & $0.7(0.3)$ \\
\hline $\mathrm{C}_{5} / \mathrm{C}_{9}$ & $5.2-64.6$ & $31.3(15.6)$ & $1.6-4.3$ & $2.8(0.7)$ & $0.1-2.7$ & $1.1(0.6)$ \\
\hline $\mathrm{C}_{6} / \mathrm{C}_{9}$ & $10.0-41.0$ & $19.8(7.21)$ & $1.3-4.6$ & $2.8(0.9)$ & $0.5-2.8$ & $1.6(0.6)$ \\
\hline
\end{tabular}

${ }^{\text {a }}$ SD denotes standard deviation $(1 \sigma){ }^{\text {b }}$ n.d. denotes not detected.

1.6) (Kawamura and Ikushima, 1993) and China's megacities (i.e., 0.6-1.1, average 0.74) (Ho et al., 2007). In contrast, the ratios are substantially higher for aged aerosols because $\mathrm{C}_{3}$ is more produced by photochemical processing of $\mathrm{C}_{4}$ (Kawamura and Ikushima, 1993). Actually, higher $\mathrm{C}_{3} / \mathrm{C}_{4}$ ratios are observed for remote marine aerosols from the North Pacific including the tropics (range: 1-11, av. 3.9), which are subjected to extensive aging during the long-range atmospheric transport (Kawamura and Sakaguchi, 1999). In this study, $\mathrm{C}_{3} / \mathrm{C}_{4}$ ratios are $0.5 \pm 0.4$ in summer, $0.9 \pm 0.1$ in spring (Table 1), and $0.7 \pm 0.2$ in winter, apparently smaller than those in aerosols affected by atmospheric aging, but similar to that of urban aerosols in China (i.e., 0.9 in summer and 0.6 in winter) (Ho et al., 2007). In addition, $C_{3}$ and $C_{4}$ can be formed by $\mathrm{OH}$ reactions of water-soluble organic compounds such as glyoxal (Tan et al., 2009) and $\mathrm{C}_{3} / \mathrm{C}_{4}$ ratios gradually 
decrease with the reaction time (Pavuluri et al., 2015). The lower $\mathrm{C}_{3} / \mathrm{C}_{4}$ ratios in summer indicate that diacid aerosols are relatively fresh but will be subjected to more atmospheric aging than in other seasons due to increasing $\mathrm{OH}$ concentrations and solar radiation.

$\mathrm{C}_{2} / \mathrm{C}_{4}$ ratios (2.0 in summer, 4.6 in spring and 4.6 in winter) in our study are found to be much smaller than those from ground observations in China during summer (inland cities in summer: av. 7.1) and winter (coastal cities in winter: av. 7.9). The lower $C_{2} / C_{4}$ and $C_{3} / C_{4}$ ratios could be also be the result of degradation of $\mathrm{C}_{2}$ and $\mathrm{C}_{3}$ in high altitudes due to increased solar radiation. However, no strong correlation $(p>0.05)$ is found between $\mathrm{C}_{2} / \mathrm{C}_{4}$ (and $\left.\mathrm{C}_{3} / \mathrm{C}_{4}\right)$ and sampling altitude although solar radiation is expected to increase with increasing altitudes. These results suggest that the degradation of higher homologous diacids (i.e., $\mathrm{C}_{4}$ ) is not an important pathway for the production of tropospheric $\mathrm{C}_{2}$ and $\mathrm{C}_{3}$ in China, and primary fossil-fuel emissions and/or secondary production from other precursors are major formation pathways of these small diacids (i.e., $\mathrm{C}_{2}, \mathrm{C}_{3}$ and $\mathrm{C}_{4}$ ).

\subsection{Cis / trans ratio}

It has been revealed that maleic acid ( $\mathrm{M}$; cis configuration) is produced by photochemical oxidation of anthropogenic aromatic hydrocarbons such as benzene and toluene, which is predominant over fumaric acid (F; trans configuration) (Sempere and Kawamura, 1996). M can be photo-isomerized to its trans isomer $(F)$ in the atmosphere under solar radiation. $\mathrm{M} / \mathrm{F}$ ratios $(4.9,4.5$ and 6.8 for summer, spring and winter, respectively) are much higher in the present study than those reported in the marine region (0.1-1.5) (Fu et al., 2013) and Chinese megacities at ground levels (2.0 and 2.2 for summer and winter, respectively) (Ho et al., 2007). This indicates that only a small fraction of maleic acid is isomerized to fumaric acid by photochemical transformation and thus SOA produced from anthropogenic emissions in the lower/middle troposphere in China is mostly fresh without substantially photochemical processing (Cong et al., 2015).

\section{$3.4 \quad \mathrm{C}_{5}\left(\mathrm{C}_{6}\right)$ to $\mathrm{C}_{9}$ diacid ratio}

The $\mathrm{C}_{6}$ (or $\mathrm{C}_{5}$ ) to azelaic acid $\left(\mathrm{C}_{9}\right)$ ratio (i.e., $\mathrm{C}_{6} / \mathrm{C}_{9}$ or $\mathrm{C}_{5} / \mathrm{C}_{9}$ ) is often used as an indicator of relative contribution from anthropogenic and biogenic sources to OA (Kawamura and Yasui, 2005). $\mathrm{C}_{6} / \mathrm{C}_{9}$ and $\mathrm{C}_{5} / \mathrm{C}_{9}$ ratios during the summer aircraft campaign are on average 17 and 28, respectively, which are $>15$ times higher than those reported at the ground surface from major Chinese cities (Ho et al., 2007; Wang et al., 2002). This comparison further supports that anthropogenic sources are an important source of OA in the high altitudes over China. Taken together with other possible SOA components (e.g., oligomers with $\mathrm{MW}>250 \mathrm{Da}$ ) produced during the oxidation of anthropogenic VOCs, our result implies that SOA formation plays an important role in OA bud- get in the troposphere especially during summer when atmospheric oxidation capacity is significantly enhanced (Shen and Wang, 2012; Su et al., 2012). It is important to note that the correlation coefficient of $\mathrm{C}_{6}$ (or $\mathrm{C}_{5}$ ) with $\mathrm{C}_{2}$ during summer $\left(r^{2}=0.39\right.$ or 0.49$)$ is lower than that obtained in winter $\left(r^{2}=0.76\right.$ or 0.59$)$ and spring $\left(r^{2}=0.95\right.$ or 0.96$)$, suggesting that $\mathrm{C}_{2}$ has a different formation pathway and/or its precursors are mostly from biogenic origins (i.e., isoprene) in summer.

\subsection{Correlation of diacids with SOA tracers and biomass burning tracers}

In the urban atmosphere, dicarboxylic acids can be emitted as primary particles from motor exhausts (Kawamura and Kaplan, 1987), biomass burning (Cong et al., 2015; Falkovich et al., 2005) and cooking emissions (Rogge et al., 1991). However, recent field, laboratory and model studies have demonstrated that aqueous-phase SOA formation from isoprene or other precursors photooxidation is a major formation pathway of small diacids (Myriokefalitakis et al., 2011; Carlton et al., 2006; Ervens et al., 2011). Furthermore, significant correlations $(r>0.70$, $p<0.05)$ are obtained between $\mathrm{C}_{2}$ and its possible precursors and intermediates such as $\omega \mathrm{C}_{2}$, Pyr, Gly and MeGly in all three campaigns (Table 2). This demonstrates that $\mathrm{C}_{2}$ is produced from its precursor compounds such as Pyr, Gly and MeGly through the following formation pathways: $\left(\mathrm{CH}_{3} \mathrm{COCOOH}, \mathrm{HCO}-\mathrm{CHO}, \mathrm{CH}_{3} \mathrm{COCHO}\right) \rightarrow \mathrm{HCO}-$ $\mathrm{COOH} \rightarrow \mathrm{HOOC}-\mathrm{COOH}$ (Carlton et al., 2009, 2007, 2006; Lim et al., 2013). We found that the correlation coefficient between Gly and $\mathrm{C}_{2}$ is higher than that between MeGly and $\mathrm{C}_{2}$ for winter and spring samples, being consistent with the fact that oxalic acid is the dominant product of glyoxal with the high yield but not for methylglyoxal (Tan et al., 2009; Lim et al., 2010). Indeed, a good correlation (Fig. 3) was found between predicted liquid water content with both OC and oxalic acid, indicating an important contribution from SOA formation via cloud processing and/or aqueous-phase oxidation. Aqueous-phase production of oxalic acid and related compounds may increase the abundances of SOA at the middle troposphere (around $2 \mathrm{~km}$ in this study), as discussed below. With the GEOS-Chem model based on the Fu et al. (2008) scheme (Fu et al., 2008), aqueous-phase SOA has a pronounced enhancement in the lower free troposphere (2-6 km) (Heald et al., 2011), which may explain to some extent the elevated levels of oxalic acid at $\sim 2 \mathrm{~km}$ in altitude.

Similarly, $\mathrm{C}_{2}$ also shows better correlations with both anthropogenic-derived SOA such as $\mathrm{C}_{5}$ and $\mathrm{C}_{6}$ for winter $\left(r^{2}=0.76\right.$ or 0.59$)$ and spring $\left(r^{2}=0.95\right.$ or 0.96$)$ samples than summer samples $\left(r^{2}=0.39\right.$ or 0.49$)$, further supporting that anthropogenic VOCs play a more important role in SOA formation than biogenic VOCs during winter and spring. A recent study reveals that air pollutants such as $\mathrm{SO}_{2}, \mathrm{NO}_{2}$, $\mathrm{PM}_{2.5}$ and $\mathrm{PM}_{10}$ are higher in winter than in summer and 
Table 2. Correlation coefficients $\left(r^{2}\right)$ among oxalic acid $\left(\mathrm{C}_{2}\right)$, pyruvic acid (Pyr), glyoxylic acid $\left(\omega \mathrm{C}_{2}\right)$, glyoxal (Gly) and methylglyoxal (MeGly) detected in aerosol samples from aircraft campaigns during summer $2003(n=14)$, spring $2004(n=16)$ and winter 2002/2003 $(n=18)$ over China. See Table 1 for abbreviations.

\begin{tabular}{|c|c|c|c|c|c|}
\hline \multicolumn{6}{|c|}{ Summer 2003} \\
\hline & $\mathrm{C}_{2}$ & Pyr & $\omega \mathrm{C}_{2}$ & Gly & MeGly \\
\hline $\mathrm{C}_{2}$ & 1.00 & & & & \\
\hline $\mathrm{Pyr}$ & 0.89 & 1.00 & & & \\
\hline$\omega \mathrm{C}_{2}$ & 0.97 & 0.95 & 1.00 & & \\
\hline Gly & 0.75 & 0.86 & 0.85 & 1.00 & \\
\hline MeGly & 0.91 & 0.97 & 0.97 & 0.90 & 1.00 \\
\hline \multicolumn{6}{|c|}{ Spring 2004} \\
\hline & $\mathrm{C}_{2}$ & Pyr & $\omega \mathrm{C}_{2}$ & Gly & MeGly \\
\hline $\mathrm{C}_{2}$ & 1.00 & & & & \\
\hline Pyr & 0.95 & 1.00 & & & \\
\hline$\omega \mathrm{C}_{2}$ & 0.97 & 0.93 & 1.00 & & \\
\hline Gly & 0.96 & 0.95 & 0.97 & 1.00 & \\
\hline MeGly & 0.93 & 0.92 & 0.94 & 0.93 & 1.00 \\
\hline \multicolumn{6}{|c|}{ Winter $2002 / 2003$} \\
\hline & $\mathrm{C}_{2}$ & Pyr & $\omega \mathrm{C}_{2}$ & Gly & MeGly \\
\hline $\mathrm{C}_{2}$ & 1.00 & & & & \\
\hline Pyr & 0.70 & 1.00 & & & \\
\hline$\omega \mathrm{C}_{2}$ & 0.98 & 0.70 & 1.00 & & \\
\hline Gly & 0.92 & 0.69 & 0.90 & 1.00 & \\
\hline MeGly & 0.85 & 0.63 & 0.83 & 0.94 & 1.00 \\
\hline
\end{tabular}

spring and these air pollutants are mostly from anthropogenic emissions (Zhang and Cao, 2015). No significant correlation $\left(r^{2}=0.28, p>0.05\right)$ is found between EC (i.e., a primary tracer for fossil-fuel biomass combustion; Zhang et al., $2015 b$ ) and $C_{2}$ in summer aerosols, whereas a good correlation is found in spring. These results indicate that primary emissions are not major sources of $\mathrm{C}_{2}$ during summer, but their contribution may be more important in spring.

Oxalic acid shows a strong positive correlation with isoprene-derived SOA tracers such as 2-methylglyceric acid (2-MGA) and $\mathrm{C}_{5}$-alkene triols (cis-2-methyl-1,3,4trihydroxy-1-butene,3-methyl-2,3,4-trihydroxy-1-butene plus trans-2-methyl-1,3,4-trihydroxy-1-butene) (Fig. 4), but a very weak correlation $\left(r^{2}=0.26, p>0.05\right)$ with 2-methyltetrols (2-methylthreitol and 2-methylerythritol). Previous studies have revealed that 2-methyltetrols could be formed through epoxy derivatives of isoprene through acid-catalyzed hydrolysis (Wang et al., 2005), whereas 2-MGA is produced by further gas-phase oxidation of its intermediates such as methacrolein and methacrylic acid from isoprene (Claeys et al., 2004; Surratt et al., 2006). Such a good correlation between 2-MGA and oxalic acid could demonstrate that oxalic acid has a very close link with the

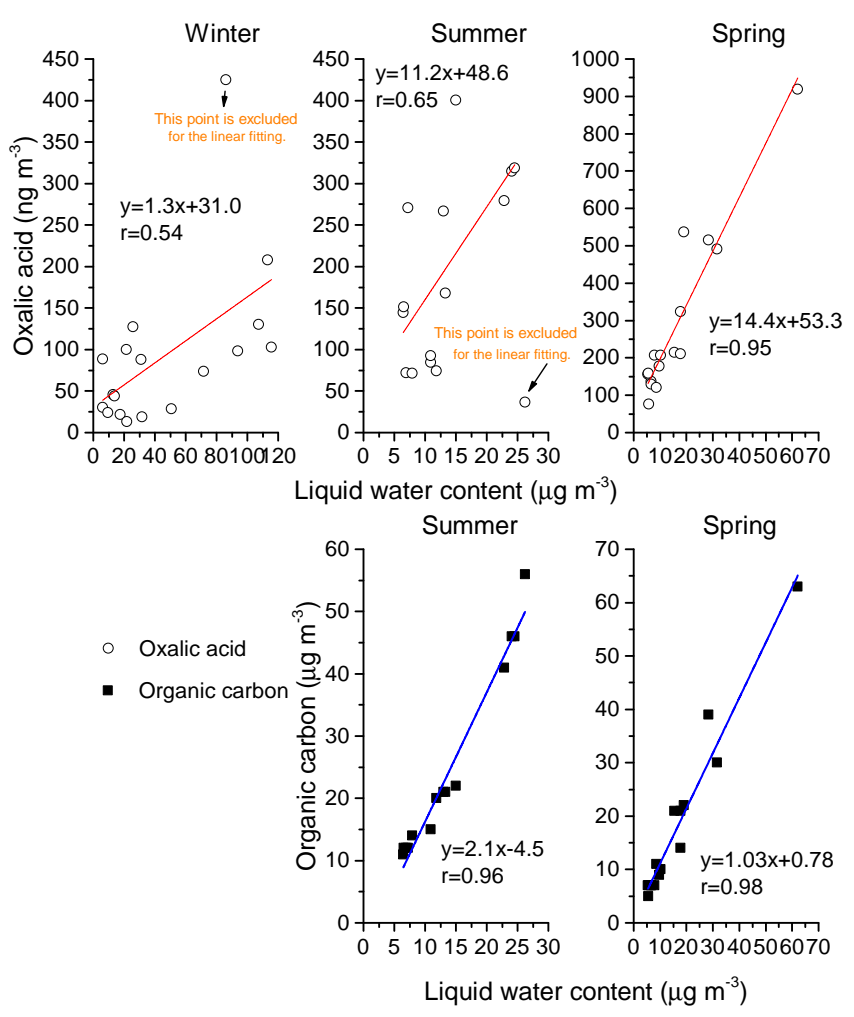

Figure 3. The linear fitting of the predicted liquid water content with organic carbon (OC) and oxalic acid aerosols during winter, summer and spring aircraft measurements over China.

higher-generation products of isoprene in the presence of relatively high $\mathrm{NO}_{x}$ (i.e., $\mathrm{NO}_{x}$ averaged to $6.6 \pm 4.0 \mathrm{ppbv}$ in summer and $3.9 \pm 3.3 \mathrm{ppbv}$ ), which could serve as precursors of oxalic acid over China. Oxalic acid also significantly correlates with $\alpha / \beta$-pinene-SOA tracers (i.e., pinonic, pinic, 3-hydroxyglutaric, and 3-methyl-1,2,3-butanetricarboxylic acid) and $\beta$-caryophyllene tracer ( $\beta$-caryophyllinic acid, see Fig. 4) (Jaoui et al., 2013).

Overall, both oxalic acid and SOA tracers are more abundant in summer than in spring, suggesting that production of these organics is associated with higher oxidation capacity, emission strength and solar radiation in summer. Based on the consistent good correlations of oxalic acid with SOA tracers derived from isoprene, monoterpene and $\beta$ caryophyllene, we propose that a large fraction of oxalic acid in the lower/middle troposphere over China is of secondary origin, i.e., via aqueous chemistry. This study highlights that oxalic acid may serve as an important tracer of SOA formation not only on the ground surface but also at high altitudes within the lower/middle troposphere. Therefore, the high abundances of small diacids $\left(\mathrm{C}_{2}-\mathrm{C}_{6}\right)$ observed in this study imply an important contribution to the OA budget from SOA production from both biogenic and anthropogenic precursors emitted from the ground surface to high altitudes over inland China. 

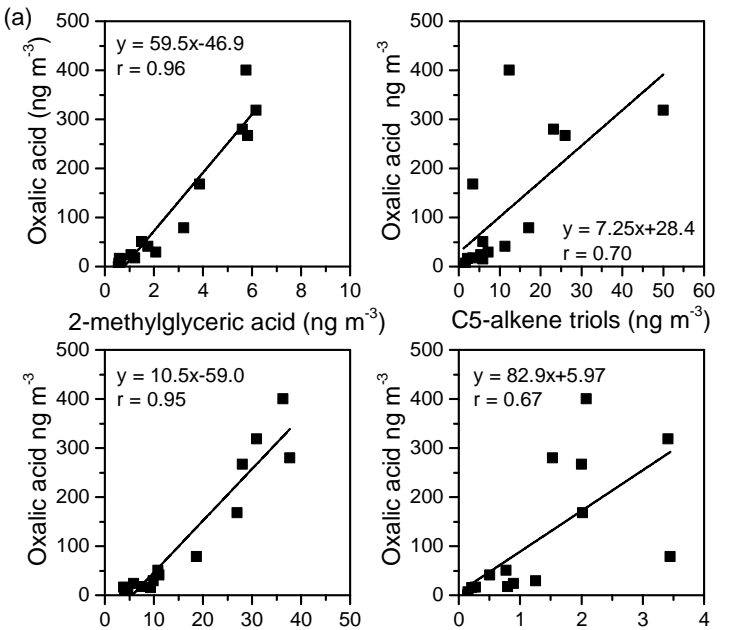

Total $\alpha / \beta$ pinene oxidation products $\beta$-caryophyllinic acid $\left(\mathrm{ng} \mathrm{m}^{-3}\right)$ $\left(\mathrm{ng} \mathrm{m}^{-3}\right)$
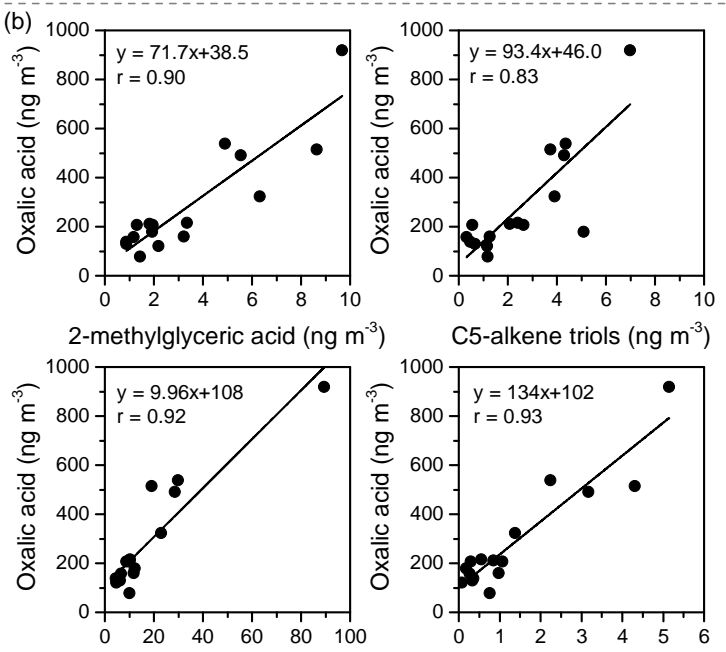

Total $\alpha / \beta$ pinene oxidation products $\beta$-caryophyllinic acid $\left(\mathrm{ng} \mathrm{m}^{-3}\right)$ $\left(\mathrm{ng} \mathrm{m}^{-3}\right)$

- Summer - Spring

Figure 4. Linear relationship of the concentrations of oxalic acid with the detected tracer compounds for secondary organic aerosols (SOA), such as isoprene SOA tracers such as 2-methylglyceric acid and $\mathrm{C}_{5}$-alkene triols (sub-total of cis-2-methyl-1,3,4-trihydroxy-1butene, 3-methyl-2,3,4-trihydroxy-1-butene, trans-2-methyl-1,3,4trihydroxy-1-butene), $\alpha / \beta$-pinene SOA tracers (subtotal of 3hydroxyglutaric acid, pinonic acid, pinic acid, 3-methyl-1,2,3butanetricarboxylic acid) and $\beta$-caryophyllene SOA tracer (i.e., $\beta$ caryophyllinic acid) from aircraft measurements over China during (a) summer and (b) spring.

The observed total concentrations of oxalic acid and other diacids identified in this study (Table 1) show the same magnitude as the levels of SOA (i.e., $299 \pm 173 \mathrm{ng} \mathrm{m}^{-3}$ in summer and $257 \pm 210 \mathrm{ng} \mathrm{m}^{-3}$ in spring) estimated by SOAtracer methods (Fu et al., 2014). It should be noted that oxalic acid is not included in the traditional "SOA tracer method" (Kleindienst et al., 2007) and therefore SOA may be under- (a)
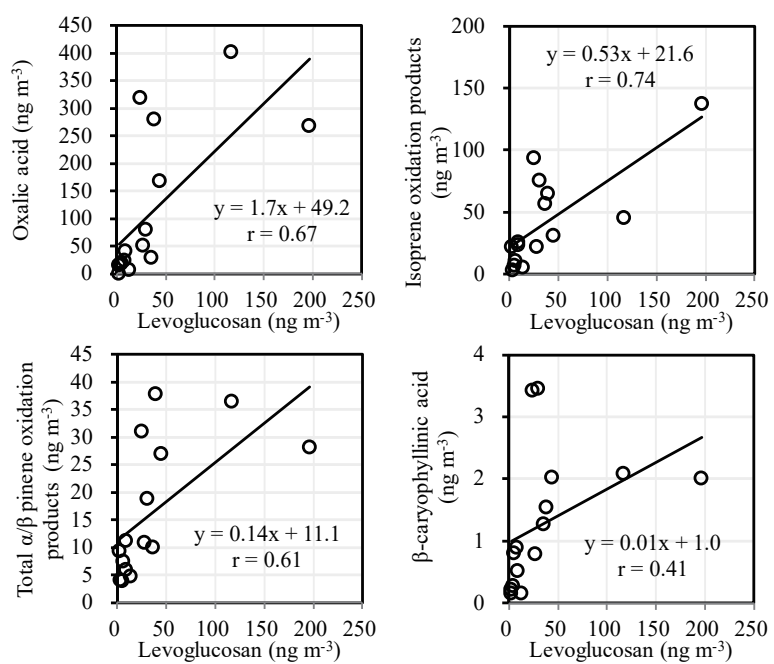

(b)
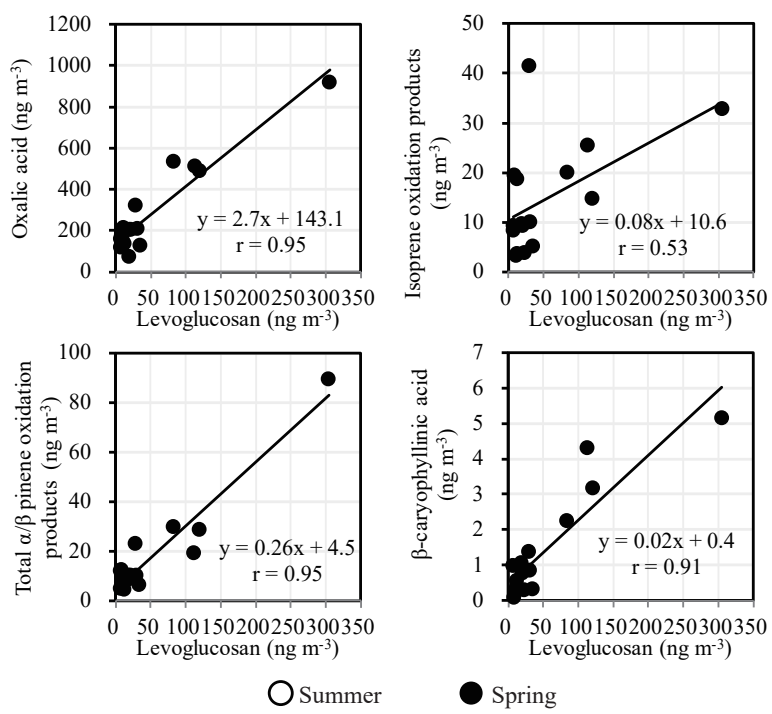

Figure 5. Linear relationship for the concentrations of levoglucosan with oxalic acid, isoprene SOA tracers, $\alpha / \beta$-pinene SOA tracers and $\beta$-caryophyllene SOA tracer from the aircraft measurements over China during (a) summer and (b) spring.

estimated if SOA is calculated by this approach. Although oxalic acid has relatively high vapor pressure, it has been observed as the most abundant individual organic compounds in aerosols (Kawamura and Bikkina, 2016). Our study together with many previous studies have revealed that oxalic acid is mostly from aqueous-phase production and is therefore of secondary origin (Myriokefalitakis et al., 2011). In addition, oxalic acid may partly exist as hydrated and/or salt forms in aerosols. Therefore, it is important to consider oxalic acid or oxalate as important SOA tracers.

Levoglucosan (1,6-Anhydro- $\beta$-D-glucopyranose) has been used as a source tracer for biomass burning (Liu et al., 2013; Fu et al., 2012). Levoglucosan shows a significant correlation with oxalic acid and also SOA tracers (Fig. 5), 

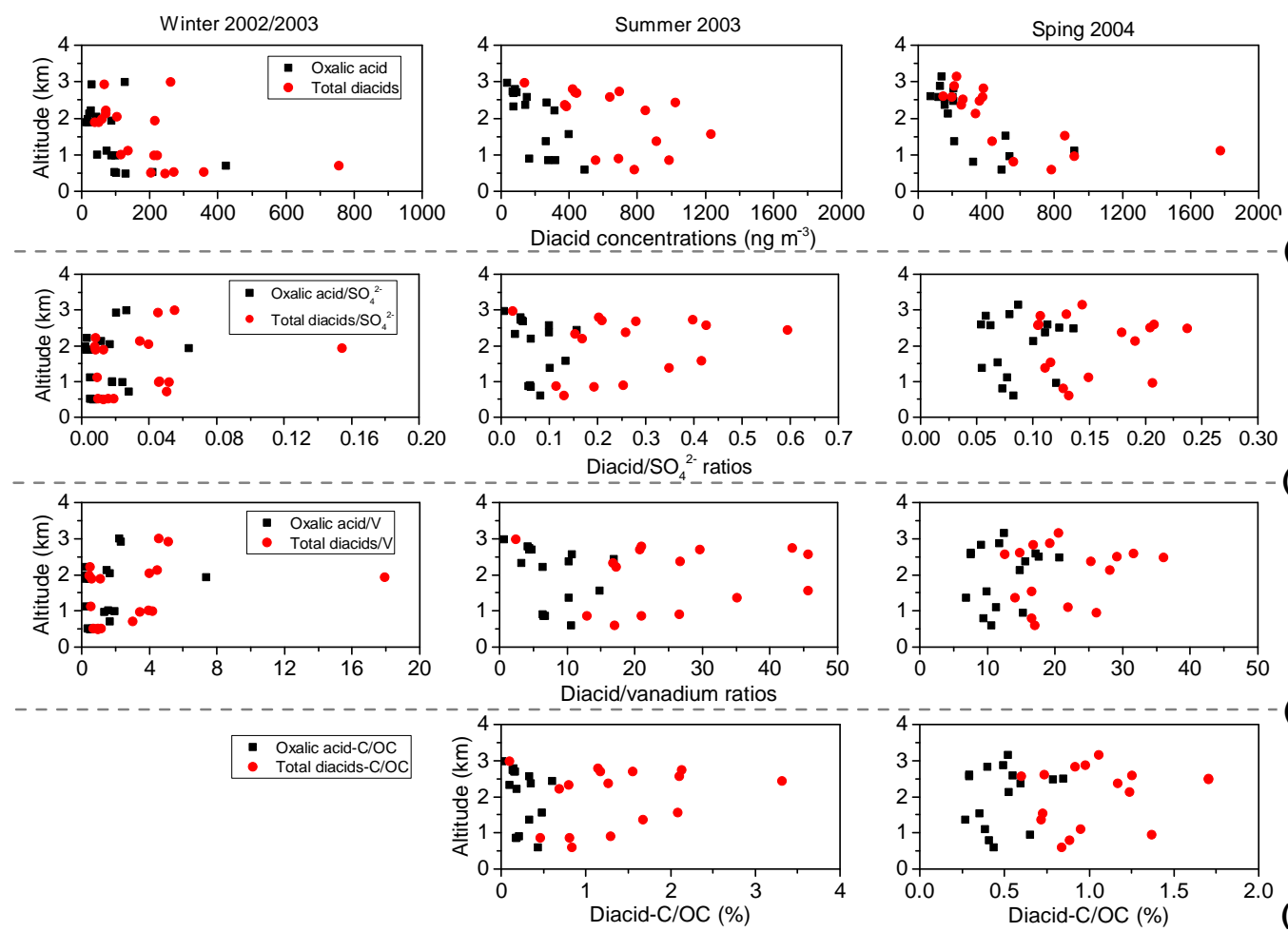

Figure 6. Vertical profiles of (a) concentrations of oxalic acid and total diacids, and their relative abundance to (b) sulfate $\left(\mathrm{SO}_{4}^{2-}\right),(\mathbf{c})$ vanadium (V) and (d) organic carbon (OC, \%) in aerosol samples collected during winter 2002 (left), summer 2003 (middle) and spring 2004 (right) aircraft campaigns over China.

indicating that biomass burning is an important source of oxalic acid and SOA. It is interesting to note that levoglucosan was more abundant in spring than in summer. In addition, regression slope and correlation coefficient between oxalic acid and levoglucosan are higher in spring (i.e., slope: $2.7, r: 0.95$ ) than in summer (i.e., slope: 1.7 , $r$ : 0.67), indicating that biomass-burning emissions play more important roles in oxalic acid formation in spring than summer. Such higher values of slope of regression line and correlation coefficient were also found between levoglucosan and $\alpha / \beta$-pinene- and $\beta$-caryophyllene-oxidation products, emphasizing an importance of springtime biomass burning. However, isoprene-oxidation products have a higher correlation coefficient in summer than in spring, implying that biomass burning in summer is an important contributor of isoprene-derived SOA.

\subsection{Vertical profiles of diacids}

As shown in Fig. 6, the highest concentrations of oxalic acid and total diacids are observed around at $2 \mathrm{~km}$ in altitude during summer with a sharp decrease toward $3 \mathrm{~km}$. However, during spring and winter, their concentrations decrease with increasing altitudes due to the atmospheric dilution during upward transport. Much clear trends are observed in the vertical profiles of oxalic acid normalized by anthropogenic tracers such as sulfate $\left(\mathrm{SO}_{4}^{2-}\right)$, vanadium and bulk OC. Interestingly, similar trends are also found in spring and winter samples, but the trends are weaker, suggesting that a secondary production of oxalic acid is largely enhanced during summer in the upper troposphere $(\sim 2 \mathrm{~km})$. A similar vertical pattern has been also reported for biogenic SOA tracers such as 2-MGA, 3-HGA and MBTCA (3-methyl-1,2,3-butanetricarboxylic acid), but not for POA such as biomass burning tracers (e.g., levoglucosan), fungal spore tracers (arabitol and mannitol), sucrose and trehalose (Fu et al., 2014). These results further demonstrate that oxalic acid is most likely produced by secondary process in the troposphere.

Oxalic acid in the high altitudes could not be simply explained by uplifting transport of pre-existing SOA produced on the ground surface because these SOA compounds relative to anthropogenic tracers, such as $\mathrm{SO}_{4}^{2-}$, vanadium and OC, significantly increased with altitude as stated above. This finding suggests that in situ SOA production by the oxidation of VOCs lifted from ground surface substantially contributes to the observed levels of oxalic acid and related species. Therefore, SOA formation in cloud or wet aerosol via the oxidation of biogenic and anthropogenic VOCs may increase concentrations of oxalic acid at higher altitudes in the troposphere. There is growing evidence in support of incloud formation of oxalic acid and related SOA. Many stud- 
ies suggest that oxalic acid is mostly produced via aqueousphase oxidation of water-soluble organics such as glyoxal, methylglyoxal, pyruvic acid and glyoxylic acid, which are oxidation intermediates of various VOCs (Ervens et al., 2004; Carlton et al., 2006; Ervens et al., 2011).

\section{Conclusions}

Based on three aircraft measurements over East Asia, this study demonstrates an aqueous-phase mechanism for SOA productions of diacids in the troposphere following correlation analysis of oxalic acid in tropospheric aerosols with other measured chemical variables including its precursors and its intermediate as well as biogenic-derived SOA from isoprene, monoterpenes and $\beta$-caryophyllene. In addition to biogenic-derived SOA compounds, anthropogenic-derived dicarboxylic acids (e.g. $\mathrm{C}_{5}$ and $\mathrm{C}_{6}$ diacids) are 4-20 times higher than those from ground measurements and even occasionally dominant over oxalic acid at altitudes higher than $2 \mathrm{~km}$ in summer, which is in contrast to the predominance of oxalic acid previously reported globally including the tropospheric and surface aerosols. The results suggest an important formation pathway associated with enhanced photochemical oxidation of anthropogenic precursors in the polluted troposphere over China. Their relative contribution of anthropogenic and biogenic sources is subject to future studies. The combination of radiocarbon $\left({ }^{14} \mathrm{C}\right)$ measurement of water-soluble organic carbon and specific SOA compounds (e.g., oxalic acid) may provide better insights on biogenic and fossil sources of SOA (Zhang et al., 2014, 2015a, 2016b; Noziere et al., 2015).

The present study demonstrates that secondary formation of oxalic acid in aqueous phase plays an important role in the SOA budget from the near surface to the lower free troposphere (i.e., $2 \mathrm{~km}$ ) over inland China, whereas dilution of pre-existing particles and VOCs, photochemical decomposition and aerosol processing may decrease the levels of oxalic acid and related compounds at higher altitudes $(>2 \mathrm{~km})$. Our findings also highlight that water-soluble diacids and other SOA components may have important impacts on the chemical compositions, physical properties and budget of OA in the polluted troposphere over China, and thus significantly affect the regional/global climate and intercontinental transport especially over the Pacific Ocean.

\section{The Supplement related to this article is available online at doi:10.5194/acp-16-6407-2016-supplement.}

Acknowledgements. The authors acknowledge the Ministry of Education, Culture, Sports, Science and Technology for financial support to perform the aircraft campaigns through Scientific
Research on Priority Areas on Atmospheric Environmental Impacts of Aerosols in East Asia (no. 416, 2002-2005). The authors also acknowledge Hong Li from Chinese Research Academy of Environmental Sciences for her support and help during the aircraft measurements. This study was also supported by a grant-in-aid nos. 14204055 and 24221001 from the Japan Society for the Promotion of Science (JSPS) as well as the Ministry of Education of China (Grant PCSIRT) and the Priority Academic Program Development of Jiangshu Higher Education Institutions (PARD).

Edited by: B. Ervens

\section{References}

Carlton, A. G., Turpin, B. J., Lim, H. J., Altieri, K. E., and Seitzinger, S.: Link between isoprene and secondary organic aerosol (SOA): Pyruvic acid oxidation yields low volatility organic acids in clouds, Geophys. Res. Lett., 33, L06822, doi:10.1029/2005g1025374, 2006.

Carlton, A. G., Turpin, B. J., Altieri, K. E., Seitzinger, S., Reff, A., Lim, H. J., and Ervens, B.: Atmospheric oxalic acid and SOA production from glyoxal: Results of aqueous photooxidation experiments, Atmos. Environ., 41, 7588-7602, 2007.

Carlton, A. G., Wiedinmyer, C., and Kroll, J. H.: A review of Secondary Organic Aerosol (SOA) formation from isoprene, Atmos. Chem. Phys., 9, 4987-5005, doi:10.5194/acp-9-4987-2009, 2009.

Cheng, Y., He, K. B., Duan, F. K., Zheng, M., Ma, Y. L., and Tan, J. H.: Positive sampling artifact of carbonaceous aerosols and its influence on the thermal-optical split of OC / EC, Atmos. Chem. Phys., 9, 7243-7256, doi:10.5194/acp-9-7243-2009, 2009.

Chow, J. C., Watson, J. G., Chen, L. W. A., Arnott, W. P., Moosmüller, H., and Fung, K.: Equivalence of elemental carbon by thermal/optical reflectance and transmittance with different temperature protocols, Environ. Sci. Technol., 38, 4414-4422, 2004.

Claeys, M., Graham, B., Vas, G., Wang, W., Vermeylen, R., Pashynska, V., Cafmeyer, J., Guyon, P., Andreae, M. O., Artaxo, P., and Maenhaut, W.: Formation of secondary organic aerosols through photooxidation of isoprene, Science, 303, 1173-1176, 2004.

Cong, Z. Y., Kawamura, K., Kang, S. C., and Fu, P. Q.: Penetration of biomass-burning emissions from South Asia through the Himalayas: new insights from atmospheric organic acids, Scientific Reports, 5, 9580, doi:10.1038/Srep09580, 2015.

Crahan, K. K., Hegg, D., Covert, D. S., and Jonsson, H.: An exploration of aqueous oxalic acid production in the coastal marine atmosphere, Atmos. Environ., 38, 3757-3764, 2004.

Enami, S., Hoffmann, M. R., and Colussi, A. J.: Stepwise Oxidation of Aqueous Dicarboxylic Acids by Gas-Phase OH Radicals, J. Phys. Chem. Lett., 6, 527-534, 2015.

Ervens, B., Feingold, G., Frost, G. J., and Kreidenweis, S. M.: A modeling study of aqueous production of dicarboxylic acids: 1. Chemical pathways and speciated organic mass production, J. Geophys. Res., 109, D15205, doi:10.1029/2004JD004575, 2004.

Ervens, B., Turpin, B. J., and Weber, R. J.: Secondary organic aerosol formation in cloud droplets and aqueous particles (aqSOA): a review of laboratory, field and model studies, Atmos. Chem. Phys., 11, 11069-11102, doi:10.5194/acp-1111069-2011, 2011. 
Falkovich, A. H., Graber, E. R., Schkolnik, G., Rudich, Y., Maenhaut, W., and Artaxo, P.: Low molecular weight organic acids in aerosol particles from Rondônia, Brazil, during the biomassburning, transition and wet periods, Atmos. Chem. Phys., 5, 781797, doi:10.5194/acp-5-781-2005, 2005.

Fountoukis, C. and Nenes, A.: ISORROPIA II: a computationally efficient thermodynamic equilibrium model for $\mathrm{K}^{+}$ $\mathrm{Ca}^{2+}-\mathrm{Mg}^{2+}-\mathrm{NH}_{4}^{+}-\mathrm{Na}^{+}-\mathrm{SO}_{4}^{2-}-\mathrm{NO}_{3}^{-}-\mathrm{Cl}^{-}-\mathrm{H}_{2} \mathrm{O}$ aerosols, Atmos. Chem. Phys., 7, 4639-4659, doi:10.5194/acp-7-4639-2007, 2007.

Fu, P., Kawamura, K., Usukura, K., and Miura, K.: Dicarboxylic acids, ketocarboxylic acids and glyoxal in the marine aerosols collected during a round-the-world cruise, Mar. Chem., 148, 22 32, 2013.

Fu, P. Q., Kawamura, K., Chen, J., Li, J., Sun, Y. L., Liu, Y., Tachibana, E., Aggarwal, S. G., Okuzawa, K., Tanimoto, H., Kanaya, Y., and Wang, Z. F.: Diurnal variations of organic molecular tracers and stable carbon isotopic composition in atmospheric aerosols over Mt. Tai in the North China Plain: an influence of biomass burning, Atmos. Chem. Phys., 12, 8359-8375, doi:10.5194/acp-12-8359-2012, 2012.

Fu, P. Q., Kawamura, K., Cheng, Y. F., Hatakeyama, S., Takami, A., Li, H., and Wang, W.: Aircraft measurements of polar organic tracer compounds in tropospheric particles $\left(\mathrm{PM}_{10}\right)$ over central China, Atmos. Chem. Phys., 14, 4185-4199, doi:10.5194/acp14-4185-2014, 2014

Fu, T. M., Jacob, D. J., Wittrock, F., Burrows, J. P., Vrekoussis, M., and Henze, D. K.: Global budgets of atmospheric glyoxal and methylglyoxal, and implications for formation of secondary organic aerosols, J. Geophys. Res., 113, D15303, doi:10.1029/2007jd009505, 2008.

Hamilton, J. F., Lewis, A. C., Reynolds, J. C., Carpenter, L. J., and Lubben, A.: Investigating the composition of organic aerosol resulting from cyclohexene ozonolysis: low molecular weight and heterogeneous reaction products, Atmos. Chem. Phys., 6, 49734984, doi:10.5194/acp-6-4973-2006, 2006.

Hatakeyama, S., Ohno, M., Weng, J. H., Takagi, H., and Akimoto, H.: Mechanism for the Formation of Gaseous and Particulate Products from Ozone-Cycloalkene Reactions in Air, Environ. Sci. Technol., 21, 52-57, 1987.

Heald, C. L., Jacob, D. J., Park, R. J., Russell, L. M., Huebert, B. J., Seinfeld, J. H., Liao, H., and Weber, R. J.: A large organic aerosol source in the free troposphere missing from current models, Geophys. Res. Lett., 32, L18809, doi:10.1029/2005g1023831, 2005.

Heald, C. L., Coe, H., Jimenez, J. L., Weber, R. J., Bahreini, R., Middlebrook, A. M., Russell, L. M., Jolleys, M., Fu, T.-M., Allan, J. D., Bower, K. N., Capes, G., Crosier, J., Morgan, W. T., Robinson, N. H., Williams, P. I., Cubison, M. J., DeCarlo, P. F., and Dunlea, E. J.: Exploring the vertical profile of atmospheric organic aerosol: comparing 17 aircraft field campaigns with a global model, Atmos. Chem. Phys., 11, 12673-12696, doi:10.5194/acp-11-12673-2011, 2011.

Henze, D. K. and Seinfeld, J. H.: Global secondary organic aerosol from isoprene oxidation, Geophys. Res. Lett., 33, L09812, doi:10.1029/2006g1025976, 2006.

Ho, K. F., Cao, J. J., Lee, S. C., Kawamura, K., Zhang, R. J., Chow, J. C., and Watson, J. G.: Dicarboxylic acids, ketocarboxylic acids, and dicarbonyls in the urban atmosphere of China, J. Geophys. Res., 112, D22S27, doi:10.1029/2006jd008011, 2007.
Ho, K. F., Lee, S. C., Ho, S. S. H., Kawamura, K., Tachibana, E., Cheng, Y., and Zhu, T.: Dicarboxylic acids, ketocarboxylic acids, alpha-dicarbonyls, fatty acids, and benzoic acid in urban aerosols collected during the 2006 Campaign of Air Quality Research in Beijing (CAREBeijing-2006), J. Geophys. Res., 115, D19312, doi:10.1029/2009jd013304, 2010.

Huang, R. J., Zhang, Y., Bozzetti, C., Ho, K. F., Cao, J. J., Han, Y., Daellenbach, K. R., Slowik, J. G., Platt, S. M., Canonaco, F., Zotter, P., Wolf, R., Pieber, S. M., Bruns, E. A., Crippa, M., Ciarelli, G., Piazzalunga, A., Schwikowski, M., Abbaszade, G., SchnelleKreis, J., Zimmermann, R., An, Z., Szidat, S., Baltensperger, U., El Haddad, I., and Prevot, A. S.: High secondary aerosol contribution to particulate pollution during haze events in China, Nature, 514, 218-222, 2014.

Jaoui, M., Kleindienst, T. E., Docherty, K. S., Lewandowski, M., and Offenberg, J. H.: Secondary organic aerosol formation from the oxidation of a series of sesquiterpenes: alpha-cedrene, betacaryophyllene, alpha-humulene and alpha-farnesene with $\mathrm{O}_{3}$, $\mathrm{OH}$ and $\mathrm{NO}_{3}$ radicals, Environ. Chem., 10, 178-193, 2013.

Kanakidou, M., Seinfeld, J. H., Pandis, S. N., Barnes, I., Dentener, F. J., Facchini, M. C., Van Dingenen, R., Ervens, B., Nenes, A., Nielsen, C. J., Swietlicki, E., Putaud, J. P., Balkanski, Y., Fuzzi, S., Horth, J., Moortgat, G. K., Winterhalter, R., Myhre, C. E. L., Tsigaridis, K., Vignati, E., Stephanou, E. G., and Wilson, J.: Organic aerosol and global climate modelling: a review, Atmos. Chem. Phys., 5, 1053-1123, doi:10.5194/acp-5-1053-2005, 2005.

Kawamura, K. and Bikkina, S.: A review of dicarboxylic acids and related compounds in atmospheric aerosols: Molecular distributions, sources and transformation, Atmos. Res., 170, 140-160, 2016.

Kawamura, K. and Ikushima, K.: Seasonal-Changes in the Distribution of Dicarboxylic-Acids in the Urban Atmosphere, Environ. Sci. Technol., 27, 2227-2235, 1993.

Kawamura, K. and Kaplan, I. R.: Motor Exhaust Emissions as a Primary Source for Dicarboxylic-Acids in Los-Angeles Ambient Air, Environ. Sci. Technol., 21, 105-110, 1987.

Kawamura, K. and Sakaguchi, F.: Molecular distributions of water soluble dicarboxylic acids in marine aerosols over the $\mathrm{Pa}-$ cific Ocean including tropics, J. Geophys. Res., 104, 3501-3509, 1999.

Kawamura, K. and Yasui, O.: Diurnal changes in the distribution of dicarboxylic acids, ketocarboxylic acids and dicarbonyls in the urban Tokyo atmosphere, Atmos. Environ., 39, 1945-1960, 2005.

Kawamura, K., Kasukabe, H., and Barrie, L. A.: Source and reaction pathways of dicarboxylic acids, ketoacids and dicarbonyls in arctic aerosols: One year of observations, Atmos. Environ., 30, 1709-1722, 1996.

Kawamura, K., Umemoto, N., Mochida, M., Bertram, T., Howell, S., and Huebert, B. J.: Water-soluble dicarboxylic acids in the tropospheric aerosols collected over east Asia and western North Pacific by ACE-Asia C-130 aircraft, J. Geophys. Res., 108, 8639, doi:10.1029/2002JD003256, 2003.

Kleindienst, T. E., Jaoui, M., Lewandowski, M., Offenberg, J. H., Lewis, C. W., Bhave, P. V., and Edney, E. O.: Estimates of the contributions of biogenic and anthropogenic hydrocarbons to secondary organic aerosol at a southeastern US location, Atmos. Environ., 41, 8288-8300, 2007. 
Lim, H. J., Carlton, A. G., and Turpin, B. J.: Isoprene forms secondary organic aerosol through cloud processing: Model simulations, Environ. Sci. Technol., 39, 4441-4446, 2005.

Lim, Y. B., Tan, Y., Perri, M. J., Seitzinger, S. P., and Turpin, B. J.: Aqueous chemistry and its role in secondary organic aerosol (SOA) formation, Atmos. Chem. Phys., 10, 1052110539, doi:10.5194/acp-10-10521-2010, 2010.

Lim, Y. B., Tan, Y., and Turpin, B. J.: Chemical insights, explicit chemistry, and yields of secondary organic aerosol from $\mathrm{OH}$ radical oxidation of methylglyoxal and glyoxal in the aqueous phase, Atmos. Chem. Phys., 13, 8651-8667, doi:10.5194/acp-13-86512013, 2013.

Liu, D., Li, J., Zhang, Y., Xu, Y., Liu, X., Ding, P., Shen, C., Chen, Y., Tian, C., and Zhang, G.: The use of levoglucosan and radiocarbon for source apportionment of $\mathrm{PM}_{2.5}$ carbonaceous aerosols at a background site in East China, Environ. Sci. Technol., 47, 10454-10461, 2013.

Muller, C., Iinuma, Y., Boge, O., and Herrmann, H.: Applications of CE-ESI-MS/MS analysis to structural elucidation of methylenecyclohexane ozonolysis products in the particle phase, Electrophoresis, 28, 1364-1370, 2007.

Myriokefalitakis, S., Tsigaridis, K., Mihalopoulos, N., Sciare, J., Nenes, A., Kawamura, K., Segers, A., and Kanakidou, M.: Incloud oxalate formation in the global troposphere: a 3-D modeling study, Atmos. Chem. Phys., 11, 5761-5782, doi:10.5194/acp11-5761-2011, 2011.

Narukawa, M., Kawamura, K., Takeuchi, N., and Nakajima, T.: Distribution of dicarboxylic acids and carbon isotopic compositions in aerosols from 1997 Indonesian forest fires, Geophys. Res. Lett., 26, 3101-3104, 1999.

Noziere, B., Kalberer, M., Claeys, M., Allan, J., D’Anna, B., Decesari, S., Finessi, E., Glasius, M., Grgic, I., Hamilton, J. F., Hoffmann, T., Iinuma, Y., Jaoui, M., Kahnt, A., Kampf, C. J., Kourtchev, I., Maenhaut, W., Marsden, N., Saarikoski, S., Schnelle-Kreis, J., Surratt, J. D., Szidat, S., Szmigielski, R., and Wisthaler, A.: The molecular identification of organic compounds in the atmosphere: state of the art and challenges, Chem. Rev., 115, 3919-3983, 2015.

Pavuluri, C. M., Kawamura, K., Mihalopoulos, N., and Swaminathan, T.: Laboratory photochemical processing of aqueous aerosols: formation and degradation of dicarboxylic acids, oxocarboxylic acids and $\alpha$-dicarbonyls, Atmos. Chem. Phys., 15, 7999-8012, doi:10.5194/acp-15-7999-2015, 2015.

Prabhakar, G., Ervens, B., Wang, Z., Maudlin, L., Coggon, M., Jonsson, H., Seinfeld, J., and Sorooshian, A.: Sources of nitrate in stratocumulus cloud water: Airborne measurements during the 2011 E-PEACE and 2013 NiCE studies, Atmos. Environ., 97, 166-173, 2014.

Pradeep Kumar, P., Broekhuizen, K., and Abbatt, J. P. D.: Organic acids as cloud condensation nuclei: Laboratory studies of highly soluble and insoluble species, Atmos. Chem. Phys., 3, 509-520, doi:10.5194/acp-3-509-2003, 2003.

Rogge, W. F., Hildemann, L. M., Mazurek, M. A., Cass, G. R., and Simonelt, B. R. T.: Sources of Fine Organic Aerosol. 1. Charbroilers and Meat Cooking Operations, Environ. Sci. Technol., 25, 1112-1125, 1991.

Sempere, R. and Kawamura, K.: Low molecular weight dicarboxylic acids and related polar compounds in the remote marine rain samples collected from western Pacific, Atmos. Environ., 30, 1609-1619, 1996.

Shen, L. and Wang, Y.: Changes in tropospheric ozone levels over the Three Representative Regions of China observed from space by the Tropospheric Emission Spectrometer (TES), 2005-2010, Chin. Sci. Bull., 57, 2865-2871, 2012.

Sorooshian, A., Varutbangkul, V., Brechtel, F. J., Ervens, B., Feingold, G., Bahreini, R., Murphy, S. M., Holloway, J. S., Atlas, E. L., Buzorius, G., Jonsson, H., Flagan, R. C., and Seinfeld, J. H.: Oxalic acid in clear and cloudy atmospheres: Analysis of data from International Consortium for Atmospheric Research on Transport and Transformation 2004, J. Geophys. Res., 111, D23S45, doi:10.1029/2005JD006880, 2006.

Sorooshian, A., Lu, M.-L., Brechtel, F. J., Jonsson, H., Feingold, G., Flagan, R. C., and Seinfeld, J. H.: On the source of organic acid aerosol layers above clouds, Environ. Sci. Technol., 41, 46474654, 2007a.

Sorooshian, A., Ng, N. L., Chan, A. W., Feingold, G., Flagan, R. C., and Seinfeld, J. H.: Particulate organic acids and overall watersoluble aerosol composition measurements from the 2006 Gulf of Mexico Atmospheric Composition and Climate Study (GoMACCS), J. Geophys. Res.-Atmos. (1984-2012), 112, D13201, doi:10.1029/2007JD008537, 2007b.

Sorooshian, A., Csavina, J., Shingler, T., Dey, S., Brechtel, F. J., Sáez, A. E., and Betterton, E. A.: Hygroscopic and chemical properties of aerosols collected near a copper smelter: implications for public and environmental health, Environ. Sci. Technol., 46, 9473-9480, 2012.

Sorooshian, A., Wang, Z., Coggon, M. M., Jonsson, H. H., and Ervens, B.: Observations of Sharp Oxalate Reductions in Stratocumulus Clouds at Variable Altitudes: Organic Acid and Metal Measurements During the 2011 E-PEACE Campaign, Environ. Sci. Technol., 47, 7747-7756, 2013.

Sorooshian, A., Crosbie, E., Maudlin, L. C., Youn, J. S., Wang, Z., Shingler, T., Ortega, A. M., Hersey, S., and Woods, R. K.: Surface and airborne measurements of organosulfur and methanesulfonate over the western United States and coastal areas, J. Geophys. Res., 120, 8535-8548, 2015.

Su, M., Lin, Y., Fan, X., Peng, L., and Zhao, C.: Impacts of global emissions of $\mathrm{CO}, \mathrm{NO}_{x}$, and $\mathrm{CH}_{4}$ on China tropospheric hydroxyl free radicals, Adv. Atmos. Sci., 29, 838-854, 2012.

Surratt, J. D., Murphy, S. M., Kroll, J. H., Ng, N. L., Hildebrandt, L., Sorooshian, A., Szmigielski, R., Vermeylen, R., Maenhaut, W., Claeys, M., Flagan, R. C., and Seinfeld, J. H.: Chemical composition of secondary organic aerosol formed from the photooxidation of isoprene, J. Phys. Chem. A, 110, 9665-9690, 2006.

Talbot, R. W., Vijgen, A. S., and Harriss, R. C.: Soluble Species in the Arctic Summer Troposphere - Acidic Gases, Aerosols, and Precipitation, J. Geophys. Res., 97, 16531-16543, 1992.

Tan, Y., Perri, M. J., Seitzinger, S. P., and Turpin, B. J.: Effects of Precursor Concentration and Acidic Sulfate in Aqueous Glyoxal$\mathrm{OH}$ Radical Oxidation and Implications for Secondary Organic Aerosol, Environ. Sci. Technol., 43, 8105-8112, 2009.

Wang, G., Niu, S., Liu, C., and Wang, L.: Identification of dicarboxylic acids and aldehydes of $\mathrm{PM}_{10}$ and $\mathrm{PM}_{2.5}$ aerosols in Nanjing, China, Atmos. Environ., 36, 1941-1950, 2002.

Wang, G. H., Kawamura, K., Hatakeyama, S., Takami, A., Li, H., and Wang, W.: Aircraft measurement of organic aerosols over China, Environ. Sci. Technol., 41, 3115-3120, 2007. 
Wang, W., Kourtchev, I., Graham, B., Cafmeyer, J., Maenhaut, W., and Claeys, M.: Characterization of oxygenated derivatives of isoprene related to 2-methyltetrols in Amazonian aerosols using trimethylsilylation and gas chromatography/ion trap mass spectrometry, Rapid Commun. Mass Sp., 19, 1343-1351, 2005.

Wonaschuetz, A., Sorooshian, A., Ervens, B., Chuang, P. Y., Feingold, G., Murphy, S. M., Gouw, J., Warneke, C., and Jonsson, H. H.: Aerosol and gas re-distribution by shallow cumulus clouds: An investigation using airborne measurements, J. Geophys. Res., 117, D17202, doi:10.1029/2012JD018089, 2012.

Yu, J. Z., Huang, X. F., Xu, J. H., and Hu, M.: When aerosol sulfate goes up, so does oxalate: Implication for the formation mechanisms of oxalate, Environ. Sci. Technol., 39, 128-133, 2005.

Zhang, Q., Jimenez, J. L., Canagaratna, M. R., Allan, J. D., Coe, H., Ulbrich, I., Alfarra, M. R., Takami, A., Middlebrook, A. M., Sun, Y. L., Dzepina, K., Dunlea, E., Docherty, K., DeCarlo, P. F., Salcedo, D., Onasch, T., Jayne, J. T., Miyoshi, T., Shimono, A., Hatakeyama, S., Takegawa, N., Kondo, Y., Schneider, J., Drewnick, F., Borrmann, S., Weimer, S., Demerjian, K., Williams, P., Bower, K., Bahreini, R., Cottrell, L., Griffin, R. J., Rautiainen, J., Sun, J. Y., Zhang, Y. M., and Worsnop, D. R.: Ubiquity and dominance of oxygenated species in organic aerosols in anthropogenically-influenced Northern Hemisphere midlatitudes, Geophys. Res. Lett., 34, L13801, doi:10.1029/2007g1029979, 2007.

Zhang, Y.-L. and Cao, F.: Fine particulate matter $\left(\mathrm{PM}_{2.5}\right)$ in China at a city level, Scientific Reports, 5, 14884, doi:10.1038/srep14884, 2015.
Zhang, Y.-L., Liu, J.-W., Salazar, G. A., Li, J., Zotter, P., Zhang, G., Shen, R.-R., Schäfer, K., Schnelle-Kreis, J., Prévôt, A. S. H., and Szidat, S.: Micro-scale $(\mu \mathrm{g})$ radiocarbon analysis of watersoluble organic carbon in aerosol samples, Atmos. Environ., 97, $1-5,2014$.

Zhang, Y.-L., Huang, R.-J., El Haddad, I., Ho, K.-F., Cao, J.-J., Han, Y., Zotter, P., Bozzetti, C., Daellenbach, K. R., Canonaco, F., Slowik, J. G., Salazar, G., Schwikowski, M., Schnelle-Kreis, J., Abbaszade, G., Zimmermann, R., Baltensperger, U., Prévôt, A. S. H., and Szidat, S.: Fossil vs. non-fossil sources of fine carbonaceous aerosols in four Chinese cities during the extreme winter haze episode of 2013, Atmos. Chem. Phys., 15, 1299-1312, doi:10.5194/acp-15-1299-2015, 2015a.

Zhang, Y. L., Schnelle-Kreis, J., Abbaszade, G., Zimmermann, R., Zotter, P., Shen, R. R., Schafer, K., Shao, L., Prevot, A. S., and Szidat, S.: Source Apportionment of Elemental Carbon in Beijing, China: Insights from Radiocarbon and Organic Marker Measurements, Environ. Sci. Technol., 49, 8408-8415, 2015 b.

Zhang, Y. L., Kawamura, K., Cao, F., and Lee, M.: Stable carbon isotopic compositions of low-molecular-weight dicarboxylic acids, oxocarboxylic acids, $\alpha$-dicarbonyls, and fatty acids: Implications for atmospheric processing of organic aerosols, J. Geophys. Res., 121, 3707-3717, 2016a.

Zhang, Y. L., Kawamura, K., Agrios, K., Lee, M., Salazar, G., and Szidat, S.: Fossil and Non-Fossil Sources of Organic and Elemental Carbon Aerosols in the Outflow from Northeast China, Environ. Sci. Technol., in press, doi:10.1021/acs.est.6b00351, $2016 b$. 